\title{
Improvement of the sanitary cleaning system within the municipal housing-and-communal services
}

\author{
Dmitry Semernin $^{1 *}$, Irina Dolgova ${ }^{2}$, Igor Mokhov $^{3}$ and Svetlana Mokhova ${ }^{3}$ \\ ${ }^{1}$ Moscow State University of Civil Engineering, 26 Yaroslavskoye Shosse, 109377, Moscow, Russia \\ ${ }^{2}$ Bauman Moscow State Technical University, 2th Baumanskaya str.,5/1, 105005, Moscow, Russia \\ ${ }^{3}$ Financial University under the Government of the Russian Federation, Leningradsky Prospect, 49, \\ 125993, Moscow, Russia
}

\begin{abstract}
The article is devoted to some questions of sanitary cleaning management in housing-and-communal services in the city. The authors revealed the tasks of activization of the innovation activity in the sphere of removal and processing of municipal solid waste as the result of the analysis of the situation existing in Russia. Separate collecting and processing of waste is offered as the perspective option. Special attention was paid to such an element as solid waste disposal. The technique of the assessment of the expediency of municipal expenses on the solid waste disposal is offered. Comparison of expenses on disposal and sorting of mixed and divided waste is carried out. The conclusion on the advantage of expediency of the divided waste is drawn. Results of this work can be used by the representatives of housing-and-communal services of the cities, responsible for sanitary cleaning, in their practical work.
\end{abstract}

\section{Introduction}

The sphere of sanitary cleaning of solid waste in Russia is an important component of the housing-and-communal services (HCS), suffers the difficulties, characteristic of this branch of the Russian economy. Difficult financial-and-economic situation of the complex is the most important aspect, including irrational tariff policy and backwardness of economic regulation, low performance of managing of the enterprises, organizational and managerial problems, difficulties with the investment attraction to this sphere.

According to the Russian legislation of municipal solid wastes are the products and subjects, which lost their qualities in the use in premises and became useless. Since January, 2019 a new concept was implemented. The most widespread types of the municipal solid wastes are:

- packaging materials: film, various container, wrappers;

- polymers;

- glass;

\footnotetext{
* Corresponding author: editor.sppk@gmail.com
} 
- textiles;

- rubber;

- food waste;

- paper.

The mubicipal solid waste disposal becomes a utility service, but not a housing one. The basic difference between housing and utilities consists in the fact, that tariffs for utilities are regulated at the national level, but tariffs for housing can be introduced by owners or managing companies. Instead of the set of the companies, which were engaged in garbage removal, single company for the whole region all subject was established on a competitive basis in 2019. It is clear, that monopolization usually brings the growth of tariffs.

The majority of foreign countries already have their experience of the creation of sanitary cleaning systems within housing-and-communal services of the city. Advantages and disadvantages of these or those management and technology solutions came to light during their functioning [1]. There is certain statistics (Table 1).

Table 1. Dynamics of formation of grated household waste in the different countries

\begin{tabular}{|c|c|c|c|}
\hline \multirow[t]{2}{*}{ Country } & \multicolumn{2}{|c|}{ Volume of municipal solid wastes, thousand tons } & \multirow{2}{*}{$\begin{array}{c}\text { Dynamics of } \\
\text { municipal solid waste } \\
\text { formation }\end{array}$} \\
\hline & 1990 & 1990 & \\
\hline \multicolumn{4}{|c|}{1 group, the countries with the increasing quantity of waste } \\
\hline Belgium & 3794 & 5386 & $142.0 \%$ \\
\hline Bulgaria & 2562 & 3628 & $141.6 \%$ \\
\hline Greece & 3000 & 3900 & $130.0 \%$ \\
\hline Iceland & 63 & 174 & $276.2 \%$ \\
\hline Spain & 12546 & 17197 & $137.1 \%$ \\
\hline Italy & 20000 & 26605 & $133.0 \%$ \\
\hline Netherlands & 6195 & 7855 & $126.8 \%$ \\
\hline Norway & 2000 & 2721 & $136.1 \%$ \\
\hline Poland & 11098 & 12183 & $109.8 \%$ \\
\hline Portugal & 3000 & 4030 & $134.3 \%$ \\
\hline France & 20322 & 37800 & $186.0 \%$ \\
\hline Sweden & 3200 & 4000 & $125.0 \%$ \\
\hline Switzerland & 4119 & 4319 & $104.9 \%$ \\
\hline \multicolumn{4}{|c|}{2 group, the countries with the decreasing quantity of waste } \\
\hline Austria & 4782 & 4241 & $88.7 \%$ \\
\hline Great Britain & 35000 & 31900 & $91.1 \%$ \\
\hline Hungary & 4900 & 4800 & $98.0 \%$ \\
\hline Germany & 50183 & 44390 & $88.5 \%$ \\
\hline Luxembourg & 224 & 187 & $83.5 \%$ \\
\hline Finland & 3100 & 2510 & $81.0 \%$ \\
\hline
\end{tabular}

Forming and ensuring functioning of the sanitary cleaning management system of a city (region) is to rely on the system of the interconnected scientific principles. It is necessary to refer to some of such principles, such as focus, systemacity, complexity, hierarchy, adequacy, stability, innovation, efficiency. The authors of the work pay the main attention to the principles of innovation and efficiency.

The principle of innovation is caused by the fact that nowadays the innovations in the humanitarian sphere directed to the improvement of quality of housing-and-communal services and the level of the population living are put in the forefront. Nowadays the technologies in Russia are significantly ahead of their global counterparts according their ecological and economic indicators [2]. The choice the most effective from them (the 
principle of efficiency) is especially important because of the variety of options of organizational and technology solutions of processing of solid waste.

\section{Materials and Methods}

The scientific-and-methodical base of management in the sphere of sanitary cleaning in the system of housing-and-communal utilities of the city is not worked out fully. The main attention is paid to the technology and ecological aspects of this problem in the available scientific and educational and methodical publications concerning sanitary cleaning/ including the works by such authors as Mirnyi A.N., Abramov N.F., Nikogosov H.N., Dreyer, A.N. Sachkov, K.S. Nikolsky, Yu.I. Marinin, A.V. Mironov and others. The term "integrated approach to the problem of the municiple solid waste" was used by V.N. Vinichenko and O.M. Cherp for the first time in Russian-speaking literature. They formulated the problem, but did not open any way for its solution. However, the complex research, in which economic, organizational, legal and technology aspects would be reflected, are not carried out as the analysis of the references proved.

The theoretical generalization and assessment of domestic and foreign experience of sanitary cleaning management at the city and territorial level were carried out on the basis of materials of periodicals and Internet data.

The methods of economical and statistical analysis, comparisons and groups, expert evaluations of economic-and-mathematical modeling were used as the special tools in the research.

\section{Results}

In modern conditions topical issue of optimization of tariffs of the housing-and-municipal sphere for export of municipal solid waste (Fig. 1).



- Expances on collecting and transportation of solid municipal wastes

- Expances on placement on polygons

- Expances on processing (sorting) of solid municipal wastes

- Payment for negative impact on the environment

- Expances of regional operators

- Investment component

Fig. 1. Structure of a tariff of the regional operator in 2019 
It is obvious that transition from burial of municipal solid waste to processing is preferable.

The following required step is the transition to the innovation schemes in the sphere of processing of solid waste and extraction of advantage from secondary resources [3, 4].

The author revealed the tasks of activization of the innovation activity in the sphere of processing of solid waste and extraction of advantage from secondary resources as the result of the analysis of the situation existing in Russia. Unfortunately, so far, the state and municipal regulation of the innovation processes in the sphere of processing of waste is insufficiently developed in Russia. There are separate legal acts raising these questions, but they have formal character and their practical application did not give the expected results. That proves the need of an integrated approach to the problem solution once again (Fig. 2).



Fig. 2. Algorithm of realization of the municipal policy of sanitary cleaning

The choice of the most effective options of organizational and technology solutions of processing of solid waste is especially important, as there is variety of them in the world practice. The use of the innovation technologies in the sphere of processing of waste is to be proved and has to consider some territorial specifics. Nowadays the most perspective innovation separate collecting and processing of the municipal solid waste is represented.

The following blocks, making the solution of the task, are offered to be considered:

1) ecological block;

2) standard and legal block;

3) economic block;

4) social block.

The influence of the implementation of the project of the innovation technologies of processing of waste on the corresponding indicators of the territory are revealed as the result of the assessment, completed in each block. Intermunicipal interests in the sphere of processing of industrial and household solid waste are considered without fail during making decision on the implementation of new technologies. 
The authors present two conditions of the economic feasibility of implementation of the innovation technology.

The first condition assumes that the volume of the waste, which is at the disposal of the waste-processing enterprise, has to be sufficient for production of a profitable production volume. This volume of waste has to be made in the territory of this municipal unit, or in the territory of the neighboring municipal units with which it is necessary to conclude intermunicipal agreements on delivery of waste [5].

The second condition is that the production volume of the waste-processing enterprise which will be demanded by potential consumers of secondary processing products has to be more than the profitable production volume $[6,7]$.

Consideration of financial and economic indicators in the economic block has to be completed from two positions, i.e. from the position of the future owner of the wasteprocessing enterprise (the purchaser of the innovation technology) [8] and from the position of the management of the territory on which processing of waste will be made [9]. The management of the territory obtains firstly the improvement of indicators of the housingand-communal services of the territory or the city, and secondly, the reduction of the areas of the earth occupied under official and unauthorized dumps, as the result of implementation of the innovation technology of processing of waste.

Costs for the mixed waste treatment consist of the costs for disposal and costs for burial or processing.

Costs for the treatment of the waste, collected separately, consist of the costs for their processing at the waste-processing enterprise (including sorting, packing, and disposal of secondary waste of sorting - so called "tails") and costs disposal.

The average costs for sorting separately collected solid municipal waste at the wasteprocessing enterprise, according to the data $[10,11,12]$ are in the range of $17 \ldots 46$ US dollars per 1 ton of incoming solid municipal wastes, if the waste-processing enterprise operates once 266 days per year. These costs include return on investment and removal of secondary sorting waste to the landfill.

Average costs on sorting of the municipal solid waste, collected separately, at the wasteprocessing enterprise are 17...46 US dollars per 1 ton of wastes, arriving 266 days in a year in case of a single-shift work waste-processing enterprise [10, 11, 12]. These expenses include return of investments and disposal of secondary waste of sorting to the polygon.

In case of the rate of 30 roubles for 1 US dollar these costs will make $510 \ldots 380$ roubles per ton.

At the same time the waste-processing enterprises with bigger performance (500 ton a day) have smaller costs, and the waste-processing enterprises with smaller (10 tons a day) have higher costs.

Average costs at the waste-processing enterprises with the efficiency of 100 tons per a day make 28 US dollars or 840 roubles per 1 ton. Such performance of waste-processing enterprises is considered to be reasonable.

2. Costs for disposal.

All the expenses on the disposal of waste can be divided into two primary groups:

1) the expenses on loading of vehicles (the collecting garbage trucks when collecting waste or heavy-load vehicles at the overload);

2) the expenses on transportation.

Expenses $R h l$ on the removal of 1 ton of waste by garbage trucks of small loading capacity can be expressed as follows:

$$
R m=R_{m}^{n}+R_{m}^{T}
$$

Expenses on removals 1 ton of waste by heavy-load transport (Rhl) can be expressed as: 


$$
R h l=R_{m h l}^{n}+R_{m h l}^{T}
$$

In turn the expenses on transportation consist of the costs depending directly on a distance, on the distance of disposal of waste which we will designate as A and the costs which are not depending on the distance of export of waste which we will designate B.

The expenses on transportation of waste by the collecting garbage trucks on the distance can be expressed as:

$$
R_{m}^{T}=A * L_{K P}+B
$$

The expenses on transportation of waste by heavy-load transport can be expressed as:

$$
R_{h l}^{T}=A * L_{K P}+B
$$

Having substituted values in expressions (1)-(2), and having equated them and having solved we will receive:

$$
L_{k p}=\frac{R_{h l}^{t}+R_{m}^{T}+B^{\prime}-B}{A-A^{\prime}}
$$

Applying formula (5) we can define economic feasibility of the use of garbage trucks of different loading capacity when collecting waste and their transportation from the place of the overload to subjects of processing and to estimate efficiency of application of waste handling stations.

In 2005 the economically reasonable tariffs for disposal of mixed waste make 188.69 roubles per m3. According to the accepted two-stage scheme of disposal, this tariff includes costs for disposal from the yards on the waste handling stations (Ministry of Railways), the overload and disposal from Ministry of Railways on a polygon or waste recycling plant. The greatest costs fall on the disposal from the yards as are made by small volumes (generally - on $6 \mathrm{~m} 3$ for 1 flight without consolidation).

Costs for disposal of separately assembled waste exclude costs for overload and export from Ministry of Railways on a polygon (costs for export of "tails" join in the cost of works at the waste-processing enterprises).

On the other hand, costs for collecting of waste because of the small single capacity of containers increase.

This growth, however, is compensated by bigger fullness of the garbage truck, because of bigger compactibility separately collected in the garbage truck in comparison with mixed.

Thus, costs will be several low costs of export? mixed.

\section{Conclusions}

Thus, the important part in such sphere of housing-and-communal services as sanitary processing is assigned to innovations. In practice separate collecting and disposal for a solid household waste is represented to the most perspective profitable.

Application of economic-mathematical methods in the sphere of transportation of solid waste allows to reach both economic, and ecological effects. The economic component is connected with reduction of expenses on fuels and lubricants, by running repair, and ecological - with reduction of load of the environment due to reduction of vehicles mileage. 


\section{References}

1. I. S. Klyueva, Modern problems of economy and finance. (Novosibirsk, 2013. - 373379).

2. A. Mottaeva, A. Borisova ,E3S Web of Conferences 138, 02015 (2019) https://doi.org/10.1051/e3sconf/201913802015

3. Vasilyeva E., Mottaeva A., E3S Web of Conferences, 91, 08051 (2019)

4. Beldeeva L.N., Lazutkina Yu.S., Komarova L.F. Ecologically safe handling of waste, (Barnaul: ALTGTU, 2009)

5. E. Vasilyeva, MATEC Web Conf., $17001050 \quad$ (2018) DOI: https://doi.org/10.1051/matecconf/201817001050

6. Golubin A.K., Maksimovich, Ekologiya and life, 2(111), 22-26 (2011)5. E. Vasilyeva, MATEC Web Conf., 170 01050 (2018) DOI: https://doi.org/10.1051/matecconf/201817001050

7. The strategy of the development of housing-and-communal services of the Russian Federation till 2035 [Digital resource] http://gorodsreda.ru/proekt-zhkkh/

8. Vasilieva E.Yu., Fundamental and applied research in the field of management, economics and trade, 27-31 (2019)

1. 9 S. Das, Bidyut $\mathrm{Kr}$ Bhattacharyya, Waste Management, 43 (2015) DOI: 10.1016/j.wasman.2015.06.033

9. E.M. Akhmetshin et al., European Research Studies Journal, 21 (Special Issue 2), 767 $776(2018)$

10. I.A. Zhilyaeva, D.G. Rodionov, Economics and entrepreneurship, 10-1 (75),. 163-167 (2016)

11. Jess W. Everett, Waste Collection solid waste collection and Transport solid waste transporting Solid wastes Transport, In book: Encyclopedia of Sustainability Science and Technology (2012) DOI: 10.1007/978-1-4419-0851-3_124

2. S. Bozhuk, N. Krasnostavskaia, N. Pletneva, T. Maslova. IOP Conference Series: Materials Science and Engineering. 497 (1). P. 012. (2019) DOI: 10.1088/1757899X/497/1/012115

3. A.R. Bril, O.V. Kalinina, I.V. Ilin. Proceedings: Proceedings of the 30th International Business Information Management Association Conference, IBIMA 2017 - Vision 2020: Sustainable Economic development, Innovation Management, and Global Growth. P. 2972-2980. (2017)

4. O. Pirogova, M. Makarevich, O. Ilina, V. Ulanov. Proceedings: IOP Conference Series: Materials Science and Engineering. P. 012129. (2019) DOI: 10.1088/1757899X/497/1/012129 